\title{
Profil status karies pada anak usia 13-15 tahun dan kadar fluor air sumur di daerah pesisir pantai dan daerah pegunungan
}

\author{
${ }^{1}$ Lidia Iswanto \\ ${ }^{2}$ Jimmy Posangi \\ ${ }^{2}$ Christy N. Mintjelungan
}

\author{
${ }^{1}$ Kandidat skripsi Program Studi Pendidikan Dokter Gigi Fakultas Kedokteran \\ ${ }^{2}$ Program Studi Pendidikan Dokter Gigi Fakultas Kedokteran \\ ${ }^{3}$ Universitas Sam Ratulangi Manado \\ Email: Lidyaiswanto@yahoo.com
}

\begin{abstract}
Dental caries is a destructive process that starts from the enamel to the dentine caused by Streptoccocus mutans bacteria. Fluorine is the most affecting chemical substance to the percentage of dental caries. Residents with geographically different locations have different caries risks. This study aimed to obtain the differences in the status of dental caries in children aged 13-15 years and the fluoride content of well water in the coastal area and mountainous area. This was a descriptive study with a cross sectional design. Samples were 60 people obtained by using purposive non-probability sampling method. Examination of dental caries was carried out by using DMF-T index and fluorine content was measured by using Atomic Absorption Spectrophotometer AAS type A230 with a wavelength of $525 \mathrm{~nm}$. The results showed that the status caries of children aged 13-15 years in the coastal area (Lihunu village) based on DMF-T index was 2.5 (low caries status) meanwhile the status of caries in children aged 13-15 years in the mountainous area (Rurukan village) based on DMF-T index was 6.2 (high caries status). Fluorine content of well water consumed in the coastal village was $0.25 \mathrm{ppm}$ (categorized as very low) and the fluorine content of well water consumed in the rural mountainous area was $0.28 \mathrm{ppm}$ (categorized as very low).
\end{abstract}

Keywords: caries status, fluoride water content, mountainous area, coastal area

\begin{abstract}
Abstrak: Karies gigi merupakan suatu proses kerusakan yang dimulai dari enamel hingga ke dentin yang disebabkan oleh bakteri Streptoccocus mutans. Fluor merupakan unsur kimia yang paling memengaruhi persentase karies gigi. Penduduk yang secara geografis letak kediamannya berbeda memiliki risiko karies yang berbeda. Penelitian ini bertujuan untuk mengetahui perbedaan status karies gigi pada anak usia 13-15 tahun dan kadar fluor air sumur di daerah pesisir pantai dan di daerah pegunungan. Jenis penelitian ini ialah deskriptif dengan desain potong lintang. Pengambilan sampel dengan menggunakan metode purposive non probability sampling dengan sampel sebanyak 60 orang. Pemeriksaan karies gigi menggunakan indeks DMF-T dan pengukuran kadar fluor menggunaan spektrofotometer serapan Atom, AAS tipe A230 dengan panjang gelombang $525 \mathrm{~nm}$. Hasil penelitian status karies pada anak usia 13-15 tahun di daerah pesisir pantai (Desa Lihunu) berdasarkan pemeriksaan indeks DMF-T sebesar 2,5 berada pada status karies rendah dan status karies pada anak usia 13-15 tahun di daerah pegunungan (Kelurahan Rurukan) berdasarkan pemeriksaan indeks DMF-T sebesar 6,2 termasuk dalam status karies tinggi. Kadar fluor air sumur yang dikonsumsi di daerah pesisir pantai sebesar 0,25 ppm (kategori sangat rendah) dan kadar fluor air sumur yang dikonsumsi di daerah pegunungan sebesar $0,28 \mathrm{ppm}$ (kategori sangat rendah).
\end{abstract}

Kata kunci: status karies, kadar fluor air, daerah pegunungan, daerah pesisir pantai 
Karies gigi merupakan penyakit gigi dan mulut yang menjadi masalah nasional di beberapa negara berkembang salah satunya di Indonesia. Berdasarkan laporan Riset Kesehatan Dasar (Riskesdas) tahun 2013 di Indonesia, prevalensi nasional karies aktif ialah 25,9\% dan indeks DMF-T nasional ialah 4,6. Wilayah Sulawesi Utara mempunyai prevalensi karies aktif sebesar $31,6 \%$ dan nilai indeks DMF-T provinsi Sulawesi Utara 5,6. Data ini menunjukan bahwa prevalensi karies aktif dan nilai DMF-T di Sulawesi Utara lebih tinggi dari rata-rata nasional. ${ }^{1}$

Karies gigi merupakan suatu proses kerusakan yang dimulai dari enamel hingga ke dentin yang disebabkan oleh bakteri Streptoccocus mutans. Bakteri tersebut dapat memfermentasikan karbohidrat seperti sukrosa dan glukosa untuk membentuk asam, menurunkan $\mathrm{pH}$ hingga $<5$, dan mengakibatkan demineralisasi pada permukaan gigi yang rentan. Proses demineralisasi dapat dihambat dengan penambahan fluor pada permukaan gigi. ${ }^{2}$

Fluor merupakan unsur kimia yang paling memengaruhi presentase karies gigi. Fluor bekerja dengan cara menghambat metabolisme bakteri plak yang dapat memfermentasi karbohidrat melalui perubahan hidroksiapatit pada enamel menjadi fluorapatit. Fluorapatit menghasilkan enamel yang tahan terhadap pelarutan asam sehingga menghambat proses demineralisasi dan meningkatkan remineralisasi yang merangsang perbaikan dan penghentian lesi karies.,

Banyak hasil penelitian menunjukkan bahwa fluor dapat mencegah karies secara efektif. Kandungan fluor dapat ditemui dalam air tanah dengan konsentrasi berbeda di tiap daerah yang dipengaruhi oleh iklim, suhu, dan kelembaban di daerah tersebut, serta jarak dengan laut. Semakin tinggi suatu daerah maka kadar fluor air semakin rendah sedangkan semakin rendah suatu daerah maka kadar fluor akan semakin tinggi. Hasil penelitian epidemiologi telah melaporkan bahwa daerah dengan kadar fluor tinggi dalam air minum memiliki persentase karies gigi yang rendah. ${ }^{5}$
Penduduk dengan letak kediaman yang berbeda secara geografis memiliki risiko karies yang berbeda pula jika dihubungkan dengan kadar fluor dalam air yang dikonsumsi yang berasal dari air sumur. Desa Lihunu berada di kecamatan Likupang Timur dan merupakan daerah pesisir pantai yang berada di sebelah Utara Laut Sulawesi dan berada di ketinggian \pm 230 meter di atas permukaan laut. Desa Lihunu terletak di pulau Bangka yang merupakan salah satu daerah dengan ketinggian terendah di kabupaten Minahasa Utara. Rurukan merupakan salah satu kelurahan yang berada di kecamatan Tomohon Timur yang berada di ketinggian sekitar 826 meter di atas permukaan laut. Kelurahan Rurukan merupakan daerah pegunungan dan termasuk dalam dataran tertinggi di Kabupaten Minahasa. ${ }^{6}$

Berdasarkan uraian tersebut, maka penulis ingin meneliti tentang perbedaan status karies gigi dan kadar fluor air sumur pada anak usia 13-15 tahun yang tinggal di daerah pesisir pantai dengan yang tinggal di daerah pegunungan yang dilaksanakan di Desa Lihunu Kecamatan Likupang Timur dan Desa Rurukan Kecamatan Tomohon Timur.

\section{BAHAN DAN METODE PENELITIAN}

Jenis penelitian yang dilakukan yaitu deskriptif dengan desain potong lintang. Penelitian ini dilakukan di Desa Lihunu Kecamatan Likupang Timur (daerah pesisir pantai) dan di Kelurahan Rurukan Kecamatan Tomohon Timur (daerah pegunungan) pada bulan Mei 2016-Juni 2016.

Populasi dalam penelitian ini yaitu seluruh anak usia 13-15 tahun di daerah pesisir pantai Desa Lihunu sebanyak 52 anak dan di daerah pegunungan Desa Rurukan sebanyak 100 anak. Jumlah populasi sebanyak 152 anak. Sampel dalam penelitian ini yaitu anak usia 13-15 yang terdaftar sebagai siswa SMP tahun ajaran 2015/2016 di wilayah Desa Lihunu dan Desa Rurukan. Jumlah sampel sebesar 30 siswa di Desa Lihunu dan 30 siswa di Desa Rurukan, diperoleh dengan metode 
purposive non probability sampling. Kriteria inklusi yaitu menggunakan air sumur untuk konsumsi setiap hari, bertempat tinggal di Desa Lihunu dan Desa Rurukan lebih dari 1 tahun, serta bersedia menjadi sampel dalam penelitian. Kriteria eksklusi tidak berada di tempat penelitian dan dalam keadaan sakit.

Alat dan bahan yang digunakan ialah untuk pemeriksaan karies gigi dan untuk pengukuran kadar fluor air sumur yaitu botol penampung air, air sumur, zirconium acid $10 \mathrm{ml}$, dan HCL $7 \mathrm{ml}$. Variabel penelitian ini yaitu status karies gigi serta kadar fluor air sumur di daerah pesisir pantai dan di daerah pegunungan. Definisi operasional

Karies gigi adalah proses penghancuran atau pelunakan dari enamel maupun dentin yang berlangsung lebih cepat pada bagian dentin daripada enamel. Gigi berlubang, hilangnya gigi, serta gigi yang ditumpat disebabkan oleh karies.

Kadar fluor air sumur dinyatakan dalam ppm (mg/liter). Sampel air sumur diperoleh dari setiap jaga di Desa Lihunu dan dari setiap jaga di Desa Rurukan. Air sumur sebanyak $100 \mathrm{ml}$ ditambahkan reagen berupa $10 \mathrm{ml}$ zirconium acid dan 7 $\mathrm{ml}$ HCL, dicampur hingga homogen dan terjadi perubahan warna, kemudian didiamkan hingga 5 menit lalu kadar fluor dibaca dengan menggunakan alat spektrofotometer A230 dengan panjang gelombang $525 \mathrm{~nm}$ (SHIMADZU Japan). Wadah atau peralatan yang dapat bereaksi dengan limbah cair harus dihindarkan, misalnya wadah atau peralatan yang terbuat dari logam yang dapat mengalami korosi oleh air yang bersifat asam. Labeling botol diberi sesuai dengan tempat dan waktu pegambilan sampel kemudian sampel dimasukan kedalam coolbox lalu dibawa ke Laboratorium.

Untuk pengukuran status DMF-T dilakukan pemeriksaan dengan kaca mulut dan sonde dimulai dari sisi kiri gigi posterior rahang bawah lalu ke anterior dan posterior kanan rahang bawah, gigi posterior kanan rahang atas lalu ke anterior rahang atas dan ke posterior kiri rahang atas. Pemeriksaan karies gigi dengan menggunakan indeks DMF-T. Pengolahan data dilakukan dengan menggunakan program komputerisasi.

\section{HASIL PENELITIAN}

Penelitian pada daerah pesisir pantai dilakukan di Desa Lihunu yang terletak di Kecamatan Likupang Timur di Pulau Bangka bagian Timur dengan ketinggian 0$230 \mathrm{~m}$ diatas permukaan laut. Mata pencaharian sebagian besar masyarakat Desa Lihunu sebagai nelayan, pekerja kebun, dan peternak. Sarana air bersih di desa Lihunu berasal dari air sumur dan dari sumber mata air. Rata-rata warga desa Lihunu memiliki sumur di setiap rumah. Sumur sangat dibutuhkan karena sebagian besar warga masih menggunakan air sumur untuk kebutuhan sehari-hari, karena jaraknya yang jauh dan harus menggunakan transportasi laut untuk membeli air minum kemasan gelon.

Kelurahan Rurukan Kecamatan Tomohon Timur merupakan satu wilayah yang terletak di Provinsi Sulawesi Utara. Secara geografis letak kota Tomohon ialah wilayah pegunungan yang terletak pada 010 18' 51' 'Lintang Utara dan 1240 49' 40" Bujur Timur, berada pada ketinggian 400-1500 meter dpl dengan kisaran suhu $18^{\circ} \mathrm{C}-30^{\circ} \mathrm{C}$. Mata pencaharian sebagian besar masyarakat Rurukan sebagai petani. Daerah Rurukan memiliki banyak sumber mata air diantaranya mata air Mahawu, Meisel, dan mata air Ayamen. Oleh karena memiliki banyak sumber air masyarakat Rurukan tidak mengalami kesulitan dalam kebutuhan air. Rata-rata setiap rumah di Rurukan memiliki sumur dengan kedalaman 7-10 meter yang digunakan oleh warga sebagai sumber kebutuhan air seharihari.

Berdasarkan hasil penelitian pada Tabel 1 terlihat bahwa jumlah responden berdasarkan jenis kelamin laki-laki di daerah pegunungan berjumlah 13 orang $(43,3 \%)$ dan responden dengan jenis kelamin perempuan sebanyak 17 orang $(56,7 \%)$. Responden di daerah pesisir pantai yang berjenis kelamin laki-laki 
sebanyak 11 orang $(36,7 \%)$ dan jenis kelamin perempuan sebanyak 19 orang $(63,3 \%)$ dengan total responden berjenis kelamin laki-laki sebanyak 24 orang $(40 \%)$ dan sebanyak 36 orang $(60 \%)$ responden berjenis kelamin wanita.

Tabel 1. Distribusi responden berdasarkan jenis kelamin dan letak geografis

\begin{tabular}{ccccc}
\hline \multirow{2}{*}{$\begin{array}{c}\text { Jenis } \\
\text { kelamin }\end{array}$} & \multicolumn{2}{c}{ Detak geografis } \\
\cline { 2 - 5 } & \multicolumn{2}{c}{ pegunungan } & \multicolumn{2}{c}{ Pesisir } \\
& $\mathrm{n}$ & $\%$ & $\mathrm{n}$ & $\%$ \\
\hline Laki-laki & 13 & 43,3 & 11 & 36,7 \\
Perempuan & 17 & 56,7 & 19 & 63,3 \\
Total & 30 & 100 & 30 & 100 \\
\hline
\end{tabular}

Tabel 2 memperlihatkan bahwa jumlah responden dengan usia 13 tahun di daerah pegunungan sebanyak 16 orang $(53 \%)$ dan sebanyak 17 orang $(56,7 \%)$ responden di daerah pesisir pantai. Responden dengan usia 14 tahun di daerah pegunungan sebanyak 9 orang $(30 \%)$ dan sebanyak 7 orang $(23,3 \%)$ di daerah pesisir pantai. Responden dengan usia 15 tahun di daerah pegunungan sebanyak 5 orang $(16,7 \%)$ dan 6 orang $(20 \%)$ responden di daerah pesisir pantai. Berdasarkan hasil penelitian yang terdapat pada Tabel 2, terlihat bahwa jumlah responden terbanyak, yakni 33 orang $(55 \%)$ berusia 13 tahun, responden berusia 14 tahun berjumlah 16 orang $(26,7 \%)$ dan yang terendah berusia 15 tahun sebanyak 11 orang $(18,3 \%)$.

Tabel 2. Distribusi responden berdasarkan usia dan letak geografis

\begin{tabular}{ccccc}
\hline & \multicolumn{3}{c}{ Letak Geografis } \\
\cline { 2 - 5 } Usia & \multicolumn{2}{c}{ Daerah } & \multicolumn{2}{c}{} \\
(Tahun) & \multicolumn{2}{c}{ pegunungan } & \multicolumn{2}{c}{ Pesisir pantai } \\
& $\mathrm{n}$ & $\%$ & $\mathrm{n}$ & $\%$ \\
\hline 13 & 16 & 53,3 & 17 & 56,7 \\
14 & 9 & 30,0 & 7 & 23,3 \\
15 & 5 & 16,7 & 6 & 20,0 \\
Total & 30 & 100 & 30 & 100 \\
\hline
\end{tabular}

Distribusi indeks DMF-T berdasarkan usia dan letak geografis daerah pegunungan memperlihatkan bahwa responden dengan usia 13 tahun (16 orang) memiliki indeks DMF-T sebesar 6,5; responden berusia 14 tahun (9 orang) memiliki indeks DMF-T sebesar 5,7; dan responden berusia 15 tahun (5 orang) memiliki indeks karies sebesar 6,0; kesemuanya termasuk dalam kategori tinggi (Tabel 3).

Distribusi indeks DMF-T berdasarkan usia dan letak geografis daerah pesisir pantai memperlihatkan responden dengan usia 13 tahun (17 orang) memiliki indeks DMF-T sebesar 2,35 termasuk dalam kategori rendah. Responden berusia 14 tahun (7 orang) memiliki indeks DMF-T sebesar 3,28 termasuk dalam kategori sedang. Responden berusia 15 tahun (6 orang) memiliki indeks karies sebesar 2,5 termasuk dalam kategori rendah (Tabel 4).

Tabel 5 menunjukan bahwa responden berjenis kelamin laki-laki di daerah pegunugan memiliki indeks DMF-T sebesar 7,1 dan termasuk dalam kategori sangat tinggi sedangkan responden berjenis kelamin perempuan memiliki indeks DMF$\mathrm{T}$ lebih rendah yaitu sebesar 5,52 dan termasuk dalam kategori tinggi.

Tabel 6 menunjukan bahwa responden berjenis kelamin laki-laki di daerah pegunungan memiliki indeks DMF-T sebesar 2 dan termasuk dalam kategori rendah sedangkan responden berjenis kelamin perempuan memiliki indeks DMF$\mathrm{T}$ lebih tinggi yaitu sebesar 2,78 dan termasuk dalam kategori sedang.

Tabel 7 menunjukan bahwa, responden dengan letak geografis di daerah pegunungan memiliki rata-rata indeks DMF-T sebesar 6,2 dan termasuk dalam kategori tinggi. Responden dengan letak geografis di daerah pesisir pantai memiliki indeks DMF-T lebih rendah yaitu sebesar 2,5 dan termasuk dalam kategori rendah. 
Tabel 3. Distribusi indeks DMF-T responden berdasarkan usia di daerah pegunungan

\begin{tabular}{cccccccc}
\hline Usia (tahun) & N & \multicolumn{4}{c}{$\begin{array}{c}\text { Komponen Indeks } \\
\text { DMF-T }\end{array}$} & Indeks & \\
& & & DMF-T & Kategori \\
\cline { 3 - 6 } & & $\mathrm{D}$ & $\mathrm{M}$ & $\mathrm{F}$ & DMF-T & & \\
\hline 13 & 16 & 101 & 3 & 0 & 104 & 6,5 & Tinggi \\
14 & 9 & 51 & 1 & 0 & 52 & 5,7 & Tinggi \\
15 & 5 & 30 & 0 & 0 & 30 & 6,0 & Tinggi \\
Total & 30 & 182 & 4 & 0 & 186 & 6,2 & Tinggi \\
\hline
\end{tabular}

Tabel 4. Distribusi DMF-T responden berdasarkan usia di daerah pesisir pantai

\begin{tabular}{cccccccc}
\hline \multirow{2}{*}{$\begin{array}{c}\text { Usia } \\
\text { tahun) }\end{array}$} & $\mathbf{N}$ & \multicolumn{4}{c}{$\begin{array}{c}\text { Komponen Indeks } \\
\text { DMF-T }\end{array}$} & $\begin{array}{c}\text { Indeks } \\
\text { DFM-T }\end{array}$ & Kategori \\
\cline { 2 - 6 } & & $\mathrm{D}$ & $\mathrm{M}$ & $\mathrm{F}$ & DMF-T & & \\
\hline 13 & 17 & 40 & 0 & 0 & 40 & 2,35 & Rendah \\
14 & 7 & 22 & 1 & 0 & 23 & 3,28 & Sedang \\
15 & 6 & 11 & 1 & 0 & 12 & 2,00 & Rendah \\
Total & 30 & 73 & 2 & 0 & 75 & 2,5 & Rendah \\
\hline
\end{tabular}

Tabel 5. Distribusi DMF-T responden berdasarkan jenis kelamin di daerah pegunungan.

\begin{tabular}{|c|c|c|c|c|c|c|c|}
\hline \multirow{2}{*}{$\begin{array}{l}\text { Jenis } \\
\text { kelamin }\end{array}$} & \multirow[t]{2}{*}{$\mathbf{N}$} & \multicolumn{4}{|c|}{ Daerah pegunungan } & \multirow{2}{*}{$\begin{array}{l}\text { Indeks } \\
\text { DMF-T }\end{array}$} & \multirow[t]{2}{*}{ Kategori } \\
\hline & & D & M & $\mathbf{F}$ & DMF-T & & \\
\hline Laki-Laki & 13 & 89 & 3 & 0 & 92 & 7,1 & Sangat tinggi \\
\hline Perempuan & 17 & 93 & 1 & 0 & 94 & 5,52 & Tinggi \\
\hline Total & 30 & 182 & 4 & 0 & 186 & 6,2 & Tinggi \\
\hline
\end{tabular}

Tabel 6. Distribusi DMF-T responden berdasarkan jenis kelamin di daerah pesisir pantai.

\begin{tabular}{|c|c|c|c|c|c|c|c|}
\hline \multirow{2}{*}{$\begin{array}{c}\text { Jenis } \\
\text { kelamin }\end{array}$} & \multirow[t]{2}{*}{$\mathbf{N}$} & \multicolumn{4}{|c|}{ Daerah pesisir pantai } & \multirow{2}{*}{$\begin{array}{c}\text { Indeks } \\
\text { DMF-T }\end{array}$} & \multirow[t]{2}{*}{ Kategor } \\
\hline & & D & $\mathbf{M}$ & $\mathbf{F}$ & DMF-T & & \\
\hline Laki-Laki & 11 & 21 & 1 & 0 & 22 & 2 & Rendah \\
\hline Perempuan & 19 & 52 & 1 & 0 & 53 & 2,78 & Sedang \\
\hline Total & 30 & 73 & 2 & 0 & 75 & 2,5 & Rendah \\
\hline
\end{tabular}

Tabel 7. Distribusi indeks DMF-T responden berdasarkan letak geografis

\begin{tabular}{cccccccc}
\hline \multirow{2}{*}{$\begin{array}{c}\text { Letak } \\
\text { geografis }\end{array}$} & $\mathbf{N}$ & \multicolumn{4}{c}{$\begin{array}{c}\text { Komponen Indeks } \\
\text { DMF-T }\end{array}$} & Indeks & Kategori \\
\cline { 3 - 6 } & & D & M & F & DMF-T & DMF-T & \\
\hline Pegunungan & 30 & 182 & 4 & 0 & 186 & 6,2 & Tinggi \\
Pesisir Pantai & 30 & 73 & 2 & 0 & 75 & 2,5 & Rendah \\
\hline
\end{tabular}

\section{Hasil pemeriksaan kadar fluor pada air sumur}

Pemeriksaan kadar fluor dalam air sumur dilakukan sebanyak 5 sampel di daerah pesisir pantai dan 5 sampel di daerah pegunungan yang digunakan oleh masyarakat setempat untuk kebutuhan air minum maupun memasak. Berdasarkan data pada Tabel 8 didapatkan bahwa sampel air sumur yang diukur dengan menggunakan spektrofoto-meter di desa Lihunu pada jaga 1,2,3 dan 5 menunjukan hasil kadar fluor yang berbeda, dan semuanya termasuk katagori sangat rendah. Sampel jaga 4 menunjukan hasil 0,62 ppm dan termasuk dalam katagori rendah. 
Tabel 8. Distribusi kadar fluor sir sumur daerah pesisir pantai

\begin{tabular}{lcc}
\hline $\begin{array}{c}\text { Lokasi sumur } \\
\text { Desa Lihunu }\end{array}$ & $\begin{array}{c}\text { Kadar fluor } \\
(\mathbf{p p m})\end{array}$ & Kategori \\
\hline Jaga 1 & 0,17 & Sangat rendah \\
Jaga 2 & 0,28 & Sangat rendah \\
Jaga 3 & 0,04 & Sangat rendah \\
Jaga 4 & 0,62 & Rendah \\
Jaga 5 & 0,11 & Sangat rendah \\
\hline Total rata-rata & 0,25 & Sangat rendah \\
\hline
\end{tabular}

Berdasarkan data pada Tabel 9 dapat dilihat bahwa kadar fluor di Kelurahan Rurukan lingkungan 1 dan 3 menunjukan hasil yang sama yaitu $0,22 \mathrm{ppm}$, sedangkan hasil pemeriksaan kadar fluor di lingkungan 5 sebesar 0,19 ppm, lingkungan 7 sebesar 0,28 ppm dan lingkungan 9 sebesar 0,23 ppm. Keseluruhan hasil pemeriksaan kadar fluor air termasuk dalam kategori sangat rendah.

Tabel 9. Distribusi kadar fluor air sumur daerah pegunungan

\begin{tabular}{ccc}
\hline $\begin{array}{c}\text { Lokasi sumur } \\
\text { Kelurahan } \\
\text { Rurukan }\end{array}$ & $\begin{array}{c}\text { Kadar } \\
\text { fluor } \\
\text { (ppm) }\end{array}$ & Kategori \\
\hline Lingkungan 1 & 0,22 & Sangat rendah \\
Lingkungan 3 & 0,22 & Sangat rendah \\
Lingkungan 5 & 0,19 & Sangat rendah \\
Lingkungan 7 & 0,28 & Sangat rendah \\
Lingkungan 9 & 0,23 & Sangat rendah \\
Total rata-rata & 0,28 & Sangat rendah \\
\hline
\end{tabular}

Tabel 10. Rata-rata DMF-T dan kadar fluor air di daerah pesisir pantai dan daerah pegunungan.

\begin{tabular}{lcccc}
\hline Daerah & $\mathbf{n}$ & $\begin{array}{c}\text { DMF } \\
\text {-T }\end{array}$ & $\begin{array}{c}\text { Rerata } \\
\text { DMF-T }\end{array}$ & $\begin{array}{c}\text { Rerata } \\
\text { kadar fluor } \\
\text { (ppm) }\end{array}$ \\
\hline Lihunu & 30 & 75 & 2,5 & 0,25 \\
Rurukan & 30 & 186 & 6,2 & 0,28 \\
\hline
\end{tabular}

Berdasarkan Tabel 10 didapatkan bahwa kedua daerah tersebut memiliki perbedaan rata-rata DMF-T. Daerah pesisir pantai memiliki rata-rata DMF-T sebesar 2,5 lebih rendah bila dibandingan daerah pegunungan yaitu memiliki rata-rata DMF-
T sebesar 6,2. Rata-rata kadar fluor daerah pesisir pantai yaitu sebesar $0,25 \mathrm{ppm}$ lebih rendah bila dibandingkan dengan daerah pegunungan yang memiliki rata-rata kadar fluor sebesar $0,28 \mathrm{ppm}$.

\section{BAHASAN}

Data hasil penelitian menunjukkan bahwa terdapat perbedaan indeks DMF-T rata-rata penduduk desa Lihunu (daerah pesisir pantai) yang beusia 13-15 tahun dengan rata-rata DMF-T sebesar 2,5 dan penduduk berusia 13-15 tahun di Kelurahan Rurukan (daerah pegunungan) sebesar 6,2. Menurut WHO angka ini menunjukkan bahwa rata-rata anak usia 13-15 tahun di Desa Lihunu mempunyai status karies dengan kategori rendah, dan rata-rata karies pada anak usia 13-15 tahun di kelurahan Rurukan dengan kategori tinggi. Hal ini sesuai dengan penelitian Musta'inah ${ }^{7}$ tahun 2012 di Kabupaten Bondowoso, dimana rata-rata DMF-T untuk daerah Asembagus (pesisir pantai) sebesar 1,31, lebih rendah dibandingkan dengan daerah Sukosari (pegunungan) yaitu 2,25.

Perbedaan nilai rata-rata DMF-T ini dapat dipengaruhi oleh beberapa faktor yang dapat menimbulkan karies gigi pada anak diantaranya ialah faktor konsumsi makanan. Masyarakat desa Lihunu pada umumnya memiliki kebiasaan mengonsumsi makanan laut setiap harinya. Makanan laut kaya akan mineral dibandingkan makanan lainnya, dan kadar fluor dalam makanan laut seperti ikan dapat mencapai 1,0 ppm. $^{8}$ Hasil penelitian yang dilakukan Fitriyanti ${ }^{9}$ menyimpulkan bahwa terdapat hubungan pola konsumsi ikan dengan kejadian karies gigi dan penyakit periodontal (indeks gingival) pada anak usia 7-12 tahun di Kabupaten Jepara karena dengan pola konsumsi ikan yang tinggi, indeks DMF-T dan indeks gingiva rendah.

Masyarakat desa Lihunu memiliki kebiasaan menangkap ikan dengan cara tradisional atau dengan cara menyelam (ba igi). Kebiasaan tersebut telah dilakukan sejak usia anak-anak hingga dewasa. Peneliti berasumsi rendahnya karies pada anak usia 13-15 tahun disebabkan karena 
kandungan fluor dalam air laut yang terpapar secara terus menerus di saat berenang atau menyelam dapat menghambat pertumbuhan bakteri penyebab karies. Hasil penelitian yang dilakukan Prajnaparamita $^{10}$ mengenai perbedaan kebutuhan perawatan gigi antara peselancar dan non-peselancar menyimpulkan bahwa air laut dapat menghambat pertumbuhan bakteri dan memberikan perlindungan pada enamel gigi, serta membantu meningkatkan kesehatan gigi dan mulut oleh karena beberapa kandungannya yang terbukti bermanfaat untuk mencegah terjadinya karies dan masalah gigi lainnya.

Hasil penelitian pada responden di desa Lihunu menujukan hasil DMF-T tertinggi pada anak usia 14 tahun yaitu sebesar 3,28 termasuk dalam kategori sedang. Peneliti berasumsi hal ini disebabkan karena kurangnya kesadaran anak untuk memeriksakan keadaan giginya dan tidak tersedianya fasilitas kesehatan gigi di daerah tersebut, hanya terdapat bidan sebagai tenaga kesehatan di desa Lihunu. Hal ini di dukung oleh penelitian yang dilakukan Goes et al. ${ }^{11}$ di Brazil pada anak usia 14-15 tahun yang menunjukkan nilai status karies dengan kategori DMF-T tinggi. Hasil penelitian tersebut menunjukkan bahwa masih terdapat kekurangan dalam bidang perawatan gigi baik preventif maupun kuratif. Hal tersebut dapat disebabkan karena pada masa remaja cenderung membiarkan keadaan giginya terserang karies.

Pada penelitian ini status DMF-T pada anak usia 13-15 tahun di Kelurahan Rurukan menunjukkan hasil yang lebih tinggi dibandingkan di desa Lihunu. Hal ini dapat disebabkan kebiasaan anak-anak mengonsumsi makanan kariogenik seperti jajanan manis, coklat, permen dan sebagainya yang sangat berpengaruh terhadap tingkat keparahan karies. Dari hasil pengamatan diketahui bahwa Kelurahan Rurukan merupakan daerah memiliki akses yang dekat dengan perkotaan; hal ini menyebabkan masyarakat lebih mudah mendapatkan makanan kariogenik. Berbeda dengan desa Lihunu yang memiliki akses yang cukup susah dan jauh serta sedikitnya pedagang yang menjualkan jajanan di daerah tersebut. Hal ini sejalan dengan penelitian Wawointana ${ }^{12}$ yang menyimpulkan terdapat hubungan antara konsumsi jajanan dan status karies gigi.

Tingginya status karies gigi pada anak usia 13-15 tahun di daerah pegunungan diakibatkan karena rendahnya kadar fluor air di daerah tersebut. Data hasil pemeriksaan kadar fluor pada air sumur Kelurahan Rurukan menunjukkan rata-rata kadar fluor sebesar $0,28 \mathrm{ppm} \mathrm{mg} / \mathrm{L}$ yang dalam kategori sangat rendah. Letak georafis yang berada di daerah pegunungan dan jarak yang jauh dengan laut mengakibatkan tingginya status karies gigi di daerah tersebut. Hasil penelitian ini juga sejalan dengan penelitian Wiratmo ${ }^{13}$ yang menunjukkan bahwa jumlah karies gigi di daerah pegunungan lebih tinggi dibandingkan di daerah pantai, yang dipengaruhi oleh kandungan fluor yang terdapat dalam air minum.

Hasil pemeriksaan kadar fluor air sumur pada penelitian di daerah pesisir pantai sebesar 0,25 ppm dan daerah pegunungan sebesar $0,28 \mathrm{ppm}$ yang menunjukkan hasil yang sangat rendah. Peraturan Menteri Kesehatan Republik Indonesia Nomor 492/MENKES/PER/IV/2010 tentang persyaratan kualitas air bersih menyatakan bahwa kadar fluor maksimum yang diperbolehkan untuk dikonsumsi dan terkandung dalam air minum sebesar 1,5 ppm, namun pada hasil pemeriksaan kadar fluor yang dilakukan keseluruan sampel tidak memenuhi kriteria tersebut.

Hasil pemeriksaan dan analisis kadar fluor air pada penelitian ini menunjukkan bahwa rata-rata kadar fluor air sumur di desa Lihunu (daerah pesisir pantai) sebesar 0,25 ppm dan termasuk dalam kategori sangat rendah. Hal ini bertolak belakang dengan penelitian yang dilakukan oleh Sumiok $^{14}$ di desa Boyongpante Dua pada tahun 2015, dimana rata-rata kadar fluor di daerah pesisir pantai sebesar 3,54 ppm dan termasuk dalam kategori sangat tinggi. Perbedaan hasil tersebut dipengaruhi oleh 
karena kurangnya kedalaman sumur yang mengakibatkan rendahnya kadar fluor dalam air. Rata-rata kedalaman sumur yang dimiliki masyarakat kelurahan Rurukan dan desa Lihunu ialah 5-10 meter. Keadaan kedalaman sumber air memengaruhi kadar fluor dalam air. Semakin dalam tanah, maka semakin tinggi juga kadar mineral yang terlarut dalam air. ${ }^{15}$

\section{SIMPULAN}

Berdasarkan hasil penelitian status karies pada anak usia 13-15 tahun dan kadar fluor air sumur di daerah pesisir pantai dan di daerah pegunungan dapat disimpulkan bahwa:

1. Status karies pada anak usia 13-15 tahun di daerah pegunungan Kelurahan Rurukan berdasarkan pemeriksaan indeks DMF-T sebesar 6,2 dengan status karies tinggi.

2. Status karies pada anak usia 13-15 tahun di daerah pesisir pantai desa Lihunu berdasarkan pemeriksaan indeks DMF-T sebesar 2,5 dengan status karies rendah.

3. Kadar fluor air sumur di daerah pegunungan (Kelurahan Rurukan) menunjukan hasil sebesar 0,28 ppm termasuk dalam kategori sangat rendah.

4. Kadar fluor air sumur di daerah pesisir pantai (Desa Lihunu) sebesar 0,25 ppm termasuk dalam kategori sangat rendah.

\section{SARAN}

1. Bagi pemerintah daerah setempat agar menyediakan fasilitas kesehatan seperti poli gigi dan melakukan program kesehatan gigi dan mulut seperti penyuluhan tentang kesehatan gigi dan mulut, fluoridasi air minum, dan pemberian tablet fluor.

2. Perlu dilakukan penelitian lebih lanjut dan menambah sampel sehingga dapat mengurangi bias dan dapat diperoleh data perbedaan indeks DMF-T dan kadar fluor air sumur yang lebih akurat.

3. Perlu diadakan sosialisasi mengenai kedalaman sumur kepada pemerintah maupun masyarakat. Semakin dalam sumur maka kandungan mineral seperti fluor akan semakin tinggi.

\section{DAFTAR PUSTAKA}

1. Riset kesehatan dasar (Riskesdas) nasional 2013. Badan Penelitian dan Pengembangan Kesehatan Departemen Kesehatan RI: 2013. p. 110-1.

2. Ongole R. Praveen BN. Text books of Oral Medicine, Oral Diagnosis and Oral Radiology. India: Elsevier, 2013; p. 405.

3. Tarigan R. Karies Gigi (2nd ed). Jakarta: EGC, 2013; p. 78-82.

4. Angela A. Pencegahan primer pada anak yang beresiko karies tinggi. Majalah Kedokteran Gigi. Dental Journal. $2005 ; 38(3)$.

5. Agtini MD, Sintawati, Indirawati T. Fluor dan kesehatan gigi. Media Litbang Kesehatan. 2005;15(2):25-30.

6. Suwelo IS. Karies Gigi Pada Anak Dengan Pelbagai Faktor Etiologi. Jakarta: EGC, 1991; p. 17-28.

7. Musta'inah I. Perbedaan status karies dan kadar fluor air sumur siswa SMA di Kecamatan Asembagus (daerah pantai) dan Kecamatan Sukosari (daerah gunung) [Skripsi]. Jember: Universitas Jember; 2012.

8. Ariningrum R, Indriasih E. Hubungan pengetahuan, sikap dan perilaku tentang karies gigi terhadap indeks DMF-T pada siswa SD Kelas VI di daerah kumuh dan tidak kumuh Kecamatan Penjaringan Jakarta Utara. Buletin Penelitian Sistem Kesehatan. 2006;9(4):198-202.

9. Fitriyanti A, Susilowati A, Darjono UNA. Perbedaan pola konsumsi ikan dan status kesehatan gigi mulut pada anak usia sekolah dasar (7-12 tahun) di daerah pesisir dan non pesisir Kabupaten Jepara. Odonto. 2014 $1(1) ; 6-10$.

10. Prajnaparamita MA. Perbedaan kebutuhan perawatan gigi antara peselancar dan non peselancar di Kabupaten Badung, Bali [Skripsi]. Denpasar: Fakultas Kedokteran Gigi Universitas Mahasaraswati; 2014.

11. Goes PSA, Watt RG, Hardy R, Sheiham A. The prevalence and severity of dental pain in 14-15 years-old Brazillian school children. Community Dent Health. 2007;24(4):217-24.

12. Wawointana IP, Umboh A, Gunawan PN. 
Hubungan konsumsi jajanan dan status karies gigi siswa di SMP NEGERI 1 Tareran. eG. 2016;4(1):5-10.

13. Wiratmo H. Pengaruh konsumsi air minum terhadap terjadinya karies pada usia 1215 tahun di daerah pantai dan pegunungan di Kabupaten Takalar. [serial online] 2008 [cited Agustus 2013]. Available from URL: http://isjd.pdii.lipi.go.id/index.php/searc h.html? act=tampil\&id $=69634 \&$ idc $=2$

14. Sumiok JB, Pangemanan DHC, Merry
N. Gambaran kadar fluor air sumur dengan karies gigi anak di Desa Boyongpante Dua Manado. Pharmacon. 2015;4(4).

15. Sunubi E. Hubungan kadar fluor air minum terhadap karies gigi pada anak sekolah dasar di Kecamatan Landono Kabupaten Konawe Selatan Provinsi Sulawesi Tenggara. Jurnal Masyarakat Epidemiologi Indonesia. 2014;2(2):87-91. 